\title{
Arrowhead (Sagittaria cuneata) as a bioindicator of nitrogen and phosphorus for prairie streams and wetlands
}

\author{
Katherine M. Standen • Patricia A. Chambers • Joseph M. Culp
}

Received: 13 March 2017 / Accepted: 31 August 2017/Published online: 27 September 2017

(C) The Author(s) 2017. This article is an open access publication

\begin{abstract}
The emergent aquatic plant, Sagittaria cuneata, is an easily-identified and commonly-found species in the Great Plains region of North America and has the potential to be a bioindicator of nitrogen (N) and phosphorus (P) because of its previouslyidentified leaf plasticity in response to nutrient conditions. To identify associations between leaf morphology and soil and water nutrients, we conducted: (1) a 10-week controlled experiment in which plants were grown in nutrient-enriched sediment, nutrientenriched water, or unamended control trials, and (2) a field study where emergent leaves were collected from
\end{abstract}

Electronic supplementary material The online version of this article (doi:10.1007/s11273-017-9576-5) contains supplementary material, which is available to authorized users.

K. M. Standen $(\bowtie) \cdot$ J. M. Culp

Biology Department and Canadian Rivers Institute, University of New Brunswick, PO Box 4400, Fredericton, NB E3B 5A3, Canada

e-mail: k.standen@unb.ca

J. M. Culp

e-mail: joseph.culp@canada.ca

P. A. Chambers

Environment and Climate Change Canada, 867 Lakeshore Rd, PO Box 5050, Burlington, ON L7R 4A6, Canada e-mail: patricia.chambers@canada.ca

\section{J. M. Culp}

Environment and Climate Change Canada, University of New Brunswick, PO Box 4400, Fredericton,

NB E3B 5A3, Canada
15 streams of varying nutrient concentrations. Plants grown in experimentally enriched sediment were more productive than those grown in enriched water or control conditions: they produced more emergent leaves and tubers, had a larger final biomass and height, and developed emergent leaves that showed a consistent increase in size and unique change in shape over time. Emergent leaves collected from field plants also showed significant variability of leaf traits; however, this variability occurred at all scales of replication (leaf, plant, quadrat, and site), with linear mixed effects modelling indicating that random chance was likely driving this variability. Although sediment nutrients were crucial to successful growth of $S$. cuneata under controlled conditions, the high variability in leaf morphology under field conditions (likely due to large natural variability at the species, population, and individual scale) make leaf plasticity of $S$. cuneata unsuitable as a bioindicator. Our results emphasize the need to quantify within and among plant variation in leaf morphology (and to clarify sampling methods) for the many taxa of aquatic macrophytes that are phenotypically plastic and notoriously difficult to classify.

Keywords Arrowhead - Sagittaria - Bioindicator · Nitrogen · Phosphorus · Great Plains 


\section{Introduction}

Bioindicators are common species, or groups of species, with easily identifiable features that exhibit plastic responses along gradients in one or more environmental variables (Holt and Miller 2011). Changes in species morphology, behavior, and physiology, presence or absence of taxa in a community, as well as the structure of the entire biotic community have all been used as indicators of stressors, both anthropogenic (pollution, land use changes) and natural (drought, flooding, etc.) (e.g., Richards and Ivey 2004). In streams (e.g., Clements and Carlisle 2000) and wetlands (e.g., Sharma and Rawat 2009), bioindicators have often been used to detect changes in water quality, such as eutrophication caused by excess nutrient inputs. Although the benthic macroinvertebrate (BMI) community has been the most commonly used taxa for assessment of water conditions (Hodkinson and Jackson 2005), aquatic macrophytes possess many traits characteristic of bioindicators: they are sessile, easily sampled and identified to genus (and often species), and respond to environmental stressors (e.g., nutrients, light, substrate texture, etc.) at the individual, population, and assemblage level. Nevertheless, compared to BMIs, relatively few studies have explored the use of macrophytes as bioindicators of environmental condition (e.g., Carbiener et al. 1990; Tremp and Kohler 1995; Robach et al. 1996; Demars and Harper 1998; Thiébaut and Muller 1999; Richards and Ivey 2004; Haury et al. 2006; Ceschin et al. 2010), especially in our region.

The aquatic macrophyte genus Sagittaria (Alismataceae) has the potential to be a useful bioindicator of nutrient status because of its easily identifiable characteristics, known plastic leaf morphology, and occurrence in and tolerance of a range of environmental conditions. Sagittaria is a submersed or emergent genus with extremely variable leaf size and shape (Arber 1920; Fernald 1950; Sculthorpe 1967): the emergent leaf blades range from lanceolate (lance-shaped) to sagittate (arrow-shaped) while the submerged leaves may be subulate (awl-shaped) or ribbon-like. Environmental conditions have been shown to influence leaf size and shape in this genus (e.g., Wooten 1986; Dorken and Barrett 2004; Richards and Ivey 2004). For example, Richards and Ivey (2004) found that $S$. lancifolia plants grown in a high $\mathrm{P}$ solution $(1 \mathrm{mM})$ produced wider emergent leaves, more leaves per plant, and were larger overall than plants grown in a low $\mathrm{P}$ solution $(10 \mu \mathrm{M})$, suggesting that higher $\mathrm{P}$ concentrations increased plant size and leaf width in S. lancifolia. Similarly, Dorken and Barrett (2004) noted that emergent leaf size of $S$. latifolia increased with fertilizer addition in both di- and monoecious populations. Water depth has also been found to influence leaf size, where increasing depth was associated with decreased leaf size as a result of energy being directed to enhance petiole length at the expense of leaf size (Wooten 1986). These predictable changes in leaf size with environmental conditions suggest that the genus Sagittaria may be a useful bioindicator of environmental stressors.

Sagittaria cuneata (Sheldon) is a widespread species across North America (Crow and Hellquist 2000) and is particularly common in parts of the Great Plains region, such as the Red River Valley in Manitoba, Canada. Here, initial conversion of native grassland to agricultural cropland or pasture, as well as present-day agricultural activities and urbanization, has led to inputs of pollutants to rivers, lakes, and wetlands, particularly sediment-bound and dissolved forms of nitrogen $(\mathrm{N})$ and phosphorus (P) but also pesticides and heavy metals (Hall et al. 1999; Dodds et al. 2004; Donald et al. 2007). The Great Plains is considered an endangered biome (Samson and Knopf 1994), with many waterbodies at risk as a result of problems associated with agriculture and urbanization, including pollution, hydrologic disturbance, modifications of riparian zone, and channelization (Dodds et al. 2004). These changes are detrimental to ecological functioning and have led to changes in instream nutrient cycling that have impaired downstream water quality (Dodds et al. 2004). Within the Great Plains region of North America, agriculturallyderived nutrient loading to the Canada-USA transboundary Red River is particularly high (Environment Canada and Manitoba Water Stewardship 2011), prompting bioindicator research in order to quickly and accurately diagnose nutrient condition of streams and wetlands in this agriculturally-dominated watershed.

The aim of this study was to determine the association between leaf morphology of Sagittaria cuneata (Alismataceae) and nutrients found in both water and sediment as a first step towards development of a bioindicator of ecosystem nutrient status. 
Sediments have been previously shown to provide the majority of nutrients to aquatic plants (Barko and Smart 1980; Carignan and Kalff 1980; Huebert and Gorham 1983); however, the water column can also provide much of the required nutrients (Chambers 1987; Robach et al. 1996; Pelton et al. 1998) especially when the ratio of sediment to water nutrient availability is low (Rattray et al. 1991). We therefore conducted two studies: (1) a controlled experiment in which plants were grown in either standardized low-nutrient water or sediment, each independently supplemented with $\mathrm{N}$ or $\mathrm{P}$ and (2) a field study to determine variability in leaf morphology in relation to in situ water and sediment nutrient concentrations. These studies allowed us to establish, first, whether $S$. cuneata biomass and leaf morphology was primarily influenced by sediment or water nutrients in the absence of confounding effects (e.g., variability in incident light, sediment composition, water depth, water clarity, and stream velocity) and, second, to quantify patterns of variation in leaf characteristics within and among natural populations of $S$. cuneata in relation to nutrient conditions of streams and wetlands in the Red River Valley of Manitoba, Canada, and more widely in the North American Great Plains.

\section{Methods}

\section{Experimental study}

Tubers (i.e., nutrient-filled, clonal structures produced on underground rhizomes) were collected from two tributaries with populations of monoecious $S$. cuneata in the Red River Valley, Manitoba, in October 2013. Tubers were cleaned with $5 \%$ bleach solution to remove harmful organisms (Hunter-Cario 2007), rinsed with distilled water, and stored moist in Ziploc bags at $4{ }^{\circ} \mathrm{C}$ to induce dormancy (adapted from McIninch and Garbisch 1991). On May 24-25th, 2014, tubers were removed from cold storage, weighed, and planted $5-8 \mathrm{~cm}$ deep in individual, $12.7 \times 12.7 \mathrm{~cm}$ square pots containing approximately $465 \mathrm{~g}$ of low-nutrient sediment composed of $1 / 3$ loam and $2 / 3$ sand. Pots were placed in water-filled coolers in the University of New Brunswick research greenhouse to break tuber dormancy. Three weeks after initial planting, $99 \%$ of tubers visibly germinated, and plants were selected from this stock based on health, and similarity in size. Ninety plants, remaining in original pots, were transferred to an outdoor facility and randomly placed in $20 \mathrm{~L}$ buckets evenly spaced on a level deck and covered by a 50\% shade cloth to reduce heat exposure. Two air pumps continuously bubbled air through each bucket to keep $\mathrm{CO}_{2}$ and oxygen levels consistent.

Three trials were established: (1) nutrient-enriched water (with four treatments of varying dosages); (2) nutrient-enriched sediment (with four treatments of varying dosages), and (3) an unenriched control (SM Table 1). All buckets received $16 \mathrm{~L}$ of de-chlorinated municipal water. For the water trial, water was enriched with potassium phosphate and ammonium nitrate. For the sediment trials, nutrients were added as slow-release fertilizer wrapped in two layers of landscaping fabric to allow for permeability and ease of replacement, and buried below the sediment surface. Water in all buckets was refreshed biweekly, and buckets were scrubbed with $5 \%$ bleach solution and subsequently rinsed to reduce algal build up. Slow-release fertilizer packs were also changed biweekly. Plants were monitored daily, and all new emergent leaves were traced and digitized using a CanoScan LiDe 110 scanner to determine if leaf size and shape changed during the experiment. After a 10-week growing period, all plants were removed from pots and sediment was rinsed from roots before being separated into parts (i.e., roots, stems, tubers, and leaves), and weighed to determine aboveground (AG) and belowground (BG) biomass, and AG:BG biomass ratio. Tubers produced by each plant were counted and weighed.

Water samples were collected on three occasions during the experiment and analyzed for total nitrogen (TNw) and phosphorus (TPw) at Environment Canada's National Laboratory for Environmental Testing using standard methods (APHA 2005a, b). Sediment samples were collected at the end of the experiment, dried at $60{ }^{\circ} \mathrm{C}$ for 5 days, ground and sieved to $1 \mathrm{~mm}$, stored frozen and later analyzed for Olsen-P ("Sed P"; Olsen et al. 1954), and nitrate and ammonium ("Sed $\mathrm{N}$ " for the sum of nitrate and ammonium; Keeney and Nelson 1982 ammonium; Willis and Gentry 1987 nitrate). 
Table 1 Sagittaria cuneata production among three nutrient trials at the termination of a 10-week nutrient enrichment experiment

\begin{tabular}{lrrrrrrr}
\hline Nutrient trial & Biomass $(\mathrm{g})$ & AG mass $(\mathrm{g})$ & \multicolumn{1}{c}{ BG mass $(\mathrm{g})$} & AG:BG & Leaves per plant & Tubers per plant & Height $(\mathrm{cm})$ \\
\hline Control & 2.39a (0.37) & 0.90a $(0.13)$ & 1.40a (0.21) & $0.53 \mathrm{a}(0.12)$ & $0.7 \mathrm{a}(0.5)$ & $0.9 \mathrm{a}(0.2)$ & $20.4 \mathrm{a}(0.6)$ \\
Sediment & 45.86b (5.66) & $22.67 \mathrm{~b}(2.89)$ & $21.89 \mathrm{~b}(2.99)$ & $0.77 \mathrm{~b}(0.07)$ & $7.1 \mathrm{~b}(0.7)$ & $15.2 \mathrm{~b}(1.5)$ & $31.7 \mathrm{~b}(1.4)$ \\
Water & 3.66a (0.27) & $1.56 \mathrm{a}(0.11)$ & $2.04 \mathrm{a}(0.17)$ & $0.55 \mathrm{a}(0.05)$ & $1.7 \mathrm{a}(0.3)$ & $2.1 \mathrm{c}(0.2)$ & $23.7 \mathrm{a}(0.6)$ \\
\hline
\end{tabular}

Values presented as average $( \pm \mathrm{SE})$, with different lower-case letters denoting significance $(p<0.05)$ among trials based on Tukey's HSD test

$A G$ aboveground, $B G$ belowground, $A G: B G$ aboveground to belowground biomass ratio

Field study

Sampling was conducted along streams in the Red River Valley, Manitoba, Canada, in mid-August 2014. The Red River Valley spans about $13,000 \mathrm{~km}^{2}$ in southern Manitoba, with approximately $76 \%$ used for agricultural activities (Red River Basin Board 2000). It is characterized by a continental climate with the warmest and coldest months, on average, being July $\left(20{ }^{\circ} \mathrm{C}\right)$ and January $\left(-14.6{ }^{\circ} \mathrm{C}\right)$, respectively, and an average $427 \mathrm{~mm}$ of annual precipitation (1980-2010 records for Morden, MB; www.climate.weatheroffice. gc.ca). We selected 15 sites that exhibited variability in nutrient emitting activities in their catchments. Of these, 10 sites were ones previously described by Yates et al. (2012), who estimated the quantity of $\mathrm{N}$ and $\mathrm{P}$ produced by human activities (livestock, human population, cropland area) within subcatchments of the Red River using a principal component analysis (PCA). We selected an additional five study sites to fill gaps in the nutrient gradient. All 15 sites were on independent tributaries within the Red River Valley, with stream orders between 2 and 4 .

Sagittaria cuneata plants were sampled along a $100 \mathrm{~m}$ reach using five, $900 \mathrm{~cm}^{2}$ quadrats distributed across the reach (adapted from Downing and Anderson 1985). Placement of quadrats was intended to be unbiased by blindly casting a quadrat downstream. Sampled plants were mature (i.e., flowering and/or bearing fruit) to facilitate species identification and present in at least $5 \mathrm{~cm}$ of water to ensure a potential influence of water chemistry. Only the three newest (or 2 , if the plant had only 2 emergent leaves), fully formed emergent leaves were collected from each of three $S$. cuneata plants per quadrat $(n=42-45$ per site; adapted from Cornelissen et al. 2003). Each leaf was scanned, weighed, placed in a standard plant press and dried at $40{ }^{\circ} \mathrm{C}$ for 5 days before being reweighed (note that four leaves were excluded due to improper drying). Water depth and height were measured at each plant. To quantify nutrients, one $500 \mathrm{~mL}$ grab water sample was collected at each site and sediment samples were collected from each quadrat $(n=5$ per site) to a depth of $10 \mathrm{~cm}$. Water sample were analyzed for TPw (APHA 2012) and TNw (USEPA 1993) at the University of Alberta. Sediment nutrient concentrations were analyzed as described previously. Light and air temperature loggers (HOBO Pendant Temperature and Light Data Logger) were placed at 11 of the 15 sites to determine average daylight (lux) and air temperature $\left({ }^{\circ} \mathrm{C}\right.$ ) over the summer (May-August 2014) (SM Table 2).

Leaf Morphology

To determine leaf size and shape, scanned leaf images from both studies were analyzed using ImageJ (Fig. 1; Rasband 1997-2014). Leaf size was denoted by six measurements (Fig. 1a). Differences in leaf shape were assessed using geometric morphometrics (Adams et al. 2004, 2012; Zelditch et al. 2004; Mitteroecker and Gunz 2009) based on 12 landmarks chosen to represent leaf shape (Fig. 1b). Euclidean coordinates were determined for each landmark on every leaf using ImageJ (Rasband 1997-2014).

\section{Statistical analyses}

All statistical analyses were conducted using the statistical software, R (version 3.0.2, R Development Core Team, Vienna). One-way fixed-effects ANOVAs were used to assess differences in final plant height, number of leaves, and tubers produced by each plant, biomass (final, $\mathrm{AG}$ and $\mathrm{BG}$ ), and $\mathrm{AG}: \mathrm{BG}$ biomass 
Table 2 Results of three-way nested ANOVA testing the significant level of replication of leaf length and leaf shape (represented by scores of PC1) of emergent leaves of Sagittaria cuneata using the model: dependent

\begin{tabular}{|c|c|c|c|c|c|c|c|c|}
\hline \multirow[t]{2}{*}{ Dependent variable } & \multirow[t]{2}{*}{ Source of variation } & \multirow[t]{2}{*}{$d f$} & \multirow[t]{2}{*}{ Mean square } & \multirow[t]{2}{*}{$F$} & \multirow[t]{2}{*}{$p$} & \multicolumn{3}{|c|}{ Variance components } \\
\hline & & & & & & & Estimate & $\%$ \\
\hline \multirow[t]{4}{*}{$\sqrt{ }$ leaf length } & Site & 14 & 3.83 & 58.50 & $<0.01$ & $\sigma_{\mathrm{S}}^{2}$ & 0.067 & 23 \\
\hline & Quad(Site) & 60 & 0.99 & 15.10 & $<0.01$ & $\sigma_{\mathrm{Q}(\mathrm{S})}^{2}$ & 0.076 & 26 \\
\hline & Plant((Quad)Site) & 150 & 0.30 & 4.59 & $<\mathbf{0 . 0 1}$ & $\sigma_{\mathrm{P}(\mathrm{Q}(\mathrm{S}))}^{2}$ & 0.081 & 28 \\
\hline & Residual & 432 & 0.07 & & & $\sigma_{\mathrm{e}}^{2}$ & 0.065 & 23 \\
\hline \multirow[t]{4}{*}{$\log _{10}(\mathrm{PC} 1+0.5)$} & Site & 14 & 0.85 & 37.52 & $<\mathbf{0 . 0 1}$ & $\sigma_{\mathrm{S}}^{2}$ & 0.017 & 30 \\
\hline & Quad(Site) & 60 & 0.11 & 4.98 & $<\mathbf{0 . 0 1}$ & $\sigma_{\mathrm{Q}(\mathrm{S})}^{2}$ & 0.007 & 13 \\
\hline & Plant((Quad)Site) & 150 & 0.05 & 2.21 & $<\mathbf{0 . 0 1}$ & $\sigma_{\mathrm{P}(\mathrm{Q}(\mathrm{S}))}^{2}$ & 0.009 & 16 \\
\hline & Residual & 432 & 0.20 & & & $\sigma_{\mathrm{e}}^{2}$ & 0.023 & 41 \\
\hline
\end{tabular}

Variance components were included for all random effects. Significance $(p<0.05)$ is indicated by bold font and variables were transformed as indicated to meet the assumptions of ANOVA variable $=\mu+$ site + quadrat $\quad($ site $)+$ plant $\quad$ (quadrat $($ site $))+\varepsilon$, where $2-3$ leaves were collected from three plants sampled in each of five quadrats at 15 sites (42-45 leaves per site, 658 total) in August 2014

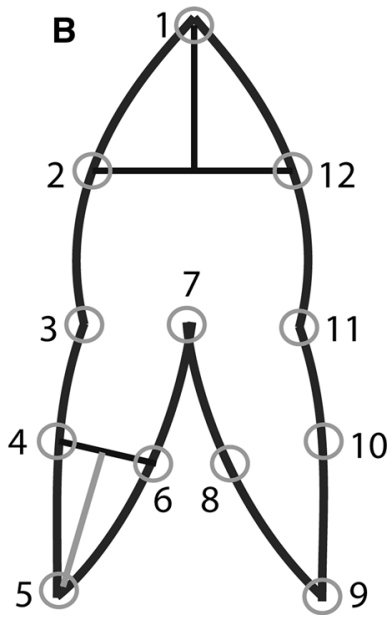

Fig. 1 Leaf diagrams depicting $\mathbf{A}$ the six size measurements taken on each leaf: blade length (1), length (2), width (3), lobe length (4), distance between lobes (5), and the surface area of each leaf (not shown), and $\mathbf{B}$ the 12 landmarks chosen on each leaf to represent leaf shape, where landmarks 2 and 12 are exactly $50 \%$ of blade length and landmarks $4,6,8$ and 10 are exactly $50 \%$ of lobe length All other landmarks are on fixed features of each leaf

ratio among experimental nutrient treatments. These analyses showed no significant differences $(p>0.05)$ of plant traits among treatments (i.e., dosages) within either the water-enriched or sediment-enriched trials. Therefore, results are presented for each trial (control, water-enriched, and sediment-enriched) with pooled

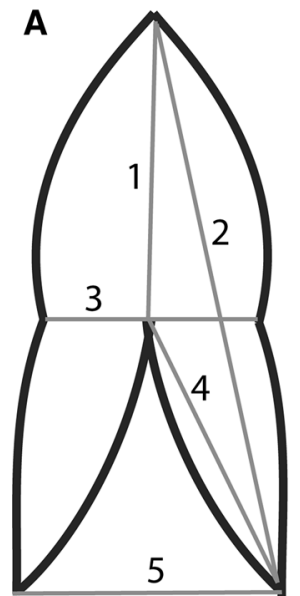

water-enriched, and sediment-enriched) with pooled treatments. When a significant main effect or interaction occurred, Tukey's HSD tests were used to further assess trends in data.

Differences in leaf shape within both studies were assessed using geometric morphometrics. In $\mathrm{R}$ package geomorph v 1.1-6 (Adams and Otarola-Castillo 2013), a separate generalized Procrustes analysis (Gower 1975; Rohlf and Slice 1990) for each study was used to rotate and scale leaves thus removing size characteristics from data, resulting in 12 sets of scaled Euclidean coordinates (i.e., $\mathrm{X}$ and $\mathrm{Y}$ coordinates for landmarks $1,2,3$, etc.) that represented the shape of individual leaves (henceforth called shape data). For each study, a principal components analysis (PCA) was conducted on shape data using $\mathrm{R}$ package geomorph v 1.1-6 (Adams and Otarola-Castillo 2013) to assess and compare individual leaf shapes. Principal components (PC) 1 and 2 were examined to ensure that each showed a meaningful shape gradient. PC1 was extracted for the field study PCA and used as a response in mixed linear effects models.

For the field study, Pearson correlations were calculated to determine relationships among leaf size characteristics, and between plant height and leaf size measurements, as well as water depth. To test for significant variation in leaf size and shape within levels of replication [leaf (two or three replicates per plant), plant (three replicates per quadrat), quadrat 
(five replicates per site), site (15 sites)], we conducted a three-way nested ANOVAs (Underwood 1997) to test the model: dependent variable $=\mu+$ Site + Quadat(Site) + Plant(Quadrat(Site $))+\varepsilon$. Variance components were estimated for all random factors in each model using R package lme4 (Bates et al. 2014) to determine at which scale the majority of random variation of leaf traits occurred.

To determine influences of nutrients on leaf morphology, nine linear mixed effects (LME) models predicting leaf traits were developed a priori based on known relationships of nutrients (water and sediment) and water depth with macrophyte growth: positive influences of TPw and TNw, singly and in combination; positive influences of SedP and SedN, singly and in combination; positive influences of both water and sediment nutrients; negative influence of water depth; and a global model with a positive influence of nutrients (water and sediment) and a negative influence of water depth. We included a random term (1l site/quadrat/plant) to account for variation at each level of replication, and a null model to determine whether random chance and/or variables outside of this study were influencing leaf traits. After assessment of a priori models, post hoc models were developed to explore the influence of additional variables (temperature, $\mathrm{pH}$, latitude, longitude, Sed $\mathrm{NO}_{3}$ ) on leaf size of $S$. cuneata. LME models were calculated using R package lme4 (Bates et al. 2014).

To determine which model was the "best" fit, the corrected Akaike Information Criterion (AICc; Sugiura 1978; Hurvich and Tsai 1991) was calculated for each model using R package AICcmodavg (Mazerolle 2015). The model with the lowest AICc value was deemed "best", and models with a change in AICc (i.e., $\Delta_{i}$ ) of less than 4 were considered plausible (i.e., competing models). Models with $\Delta_{i}$ of 4-7 were considered less plausible, and values over seven were determined as implausible (as suggested by Anderson 2008).

\section{Results}

\section{Experimental study}

Comparison of plant traits among the three trials showed that plants grown in nutrient-enriched sediments were more productive than water-enriched and control trials (Table 1). Of plants in the sediment trial, 87 and $100 \%$ produced emergent leaves and tubers, respectively. In contrast, 65 and $98 \%$ of water trial and $20 \%$ and $70 \%$ of control trial plants produced emergent leaves and tubers, respectively. Final biomass $\left(F_{2,77}=102.56\right)$, BG $\left(F_{2,77}=85.86\right)$ and AG biomass $\left(F_{2,77}=101.71\right), \quad \mathrm{AG}: \mathrm{BG}$ biomass ratio $\left(F_{2,77}=5.92\right)$, final plant height $\left(F_{2,77}=5.62\right)$, and both number of leaves $\left(F_{2,77}=25.64\right)$ and number of tubers $\left(F_{2,77}=101.96\right)$ per plant were significantly different ( $p<0.01$ for all comparisons) among the three nutrient trials, with sediment trial plants having higher biomass (final, $\mathrm{AG}$ and $\mathrm{BG}$ ), larger $\mathrm{AG}$ :BG biomass ratio, greater height, and more leaves and tubers than water and control trials $(p<0.05$, Tukey's HSD test; Table 1). In addition, water trial plants produced 2.5X more emergent leaves and had significantly more tubers per plant than control trial plants.

Leaf length was chosen to represent leaf size because it had strong $(r>0.80)$, significant $(p<0.05)$ correlations with all other size characteristics (Fig. 1a). Leaf length was significantly influenced by an interaction between nutrient trial and weeks $\left(F_{8,172}=9.03, p<0.01\right)$. Leaf length did not differ ( $p>0.10$, Tukey's HSD test) among the 3 trials during the first week in which emergent leaves were present (i.e., week 3); however, during subsequent weeks, plants in the sediment trial produced larger emergent leaves than those grown in either the water or control trials (Fig. 2). In the case of the sediment trial, leaves were smallest during week 3, largest during weeks 7 and 8 , and intermediate and similar in size during weeks $4,5,6$, and 10. For plants in the water and control trials, emergent leaves remained small and similar in size throughout the experiment, and were not produced in weeks 9 and 10 .

Similar to leaf length, shape of emergent $S$. cuneata leaves varied among the three trials and over time (Fig. 3). About $57 \%$ of shape variation was explained by gradients associated with PC 1 and PC 2, which corresponded to the distance between lobes (variation between landmarks 5 and 9; Fig. 1b) and lobe length (variation between landmarks 5 and 7 , or 9 and 7 ; Fig. 1b), respectively. Leaves produced in the control trial were of a similar shape (Fig. 3), though the control trial had low replication of emergent leaves $(n=7)$. Similar to control plants, the average shape of water-trial leaves showed little variation over the experiment. In contrast, average leaf shape of the 


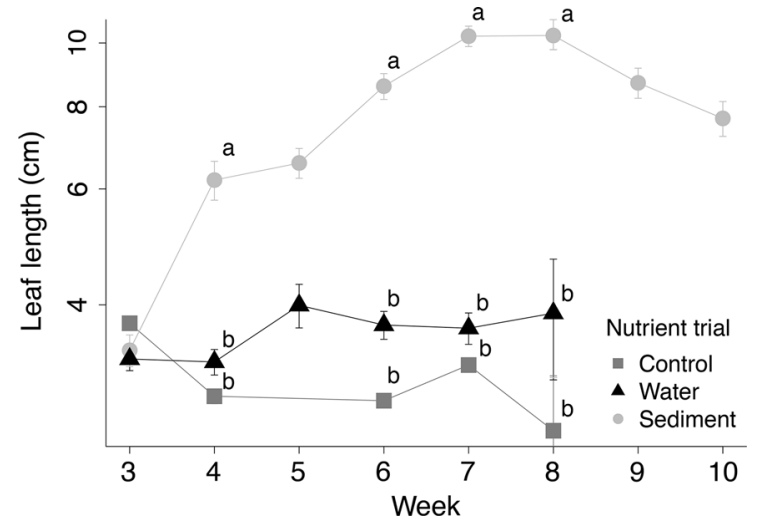

Fig. 2 Average length ( $\pm \mathrm{SE}$; on a logarithmic scale) of emergent Sagittaria cuneata leaves $(\mathrm{n}=2-40$ for each trial and week, total $=272$ leaves). Plants were grown in 1 of 3 different nutrient trials during a 10 -week nutrient addition experiment. Different letters for a given week denote significance ( $p<0.05$, Tukey's HSD test) among trials. Plants began producing emergent leaves in week 3 ; water-enriched and/or control plants did not produce emergent leaves in weeks 5, 9 and 10

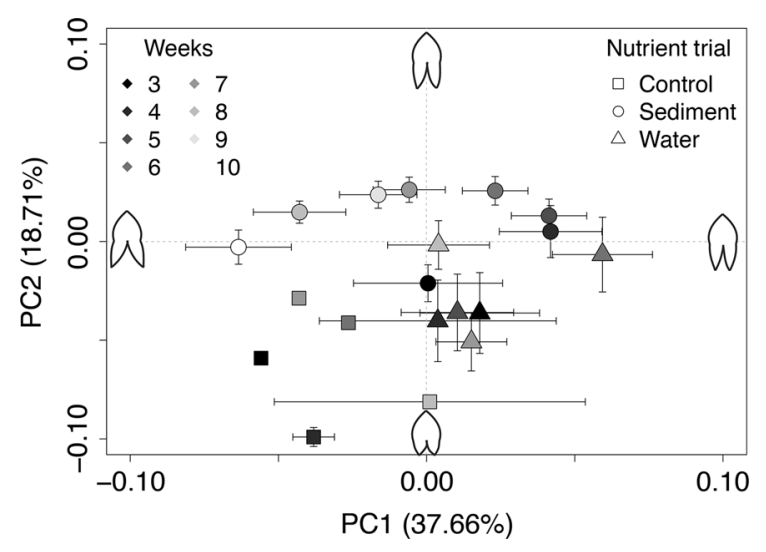

Fig. 3 Bivariate plot of average $( \pm \mathrm{SE})$ principal components (PC) 1 and 2 scores depicting variation in landmark coordinates (i.e., shape) of emergent Sagittaria cuneata leaves $(n=2-40$ for each trial per week, total $=272$ leaves) grown in three nutrient trials during a 10 -week experiment Leaves began emerging in week 3 of the experiment. Line drawings illustrate the change in leaf shape depicted by each axis, with PC 1 associated with a change in lobe distance (Fig. 1b, landmark 5 and 9) and PC 2 indicative of a change in lobe length (Fig. 1b, landmark 5 and 7 , or 9 and 7 )

sediment trial changed weekly. On average, leaves produced by plants in the sediment trial also had longer lobes compared to those produced in the water and control trials.

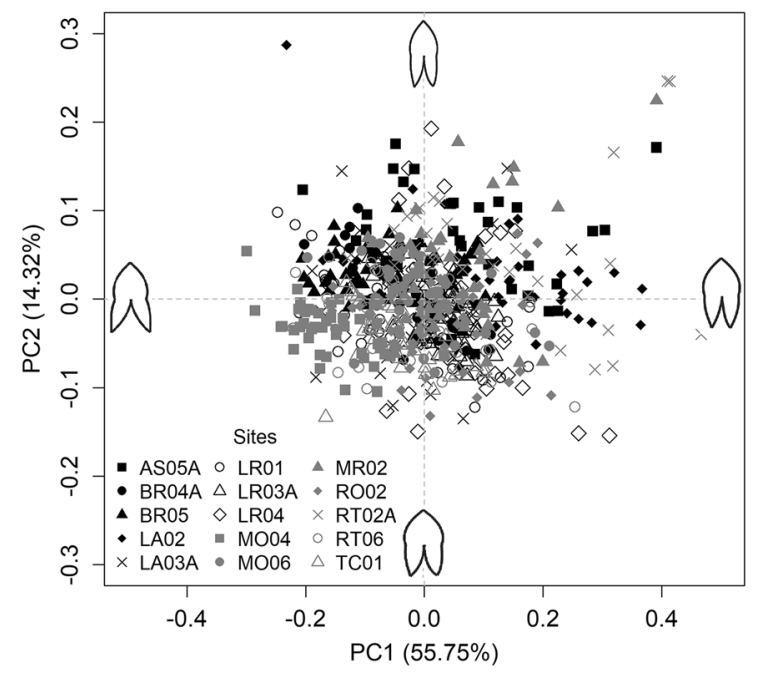

Fig. 4 Bivariate plot of unaveraged $(n=42-45$ leaves per site, 658 total leaves) principal components (PC) 1 and 2 scores summarizing variation in 12 sets of Euclidean landmark coordinates (i.e., shape, see Fig. 3) of Sagittaria cuneata leaves collected from 15 tributary sites in the Red River Valley, Manitoba, Canada, in August 2014

Field study

Principal components analysis (PCA) showed that leaf shape was variable within and among sites, with little distinct grouping (Fig. 4). Principal component (PC) 1 explained about $56 \%$ of leaf shape variation and corresponded to differences in the rotation of the lobes, whereas PC 2 explained $14 \%$ of shape variation and related to width of leaf blades. Three-way nested ANOVA of leaf size also showed that leaf length varied significantly at site, quadrat, and plant replication scales; variance components for all random effects indicated that variation was similar at all four scales (about 25\%; Table 2). In contrast, nested ANOVA of leaf shape (represented by scores of PC1) showed greatest variation at the leaf scale (41\%), followed by site $(30 \%)$ and quadrat $(13 \%)$ and plant (16\%) scale.

Comparison of a priori linear mixed effects models using AICc indicated that, for leaf length (Table 3) and leaf shape (Table 4), the null model was the "best" model. For leaf shape, all other models were greater than 9 AICc units from the null model, suggesting that none of the variables, singly or in combination, were influencing leaf shape of $S$. cuneata. For leaf length, however, TNw is considered a plausible model with a $\Delta_{\mathrm{i}}$ of 2.55 units and a weight 
Table 3 Comparison of a priori and post hoc models for predicting (a) leaf length and (b) leaf shape of emergent Sagittaria cuneata leaves in 15 streams of the Red River
Valley, Manitoba, Canada in August 2014, using linear mixed effects (LME) models and corrected Akaike Information Criterion (AICc)

\begin{tabular}{|c|c|c|c|c|c|c|c|}
\hline Model \# & Model variables & $R_{M}^{2}$ & $R_{C}^{2}$ & $\mathrm{AIC}_{\mathrm{c}}$ & $\Delta_{\mathrm{i}}$ & Likelihood & $\omega_{\mathrm{i}}$ \\
\hline \multicolumn{8}{|l|}{ A priori } \\
\hline & Null model & 0 & 0.7654 & 541.95 & 0 & 1.000 & 0.710 \\
\hline 2 & $\mathrm{TNw}$ & 0.1037 & 0.7712 & 544.50 & 2.55 & 0.279 & 0.198 \\
\hline 1 & $\mathrm{TPw}$ & 0.0498 & 0.7738 & 548.04 & 6.09 & 0.048 & 0.034 \\
\hline 7 & TNw, TPw & 0.1086 & 0.7745 & 548.49 & 6.54 & 0.038 & 0.027 \\
\hline 4 & $\sqrt{ }$ Sed N & 0.0134 & 0.7749 & 549.93 & 7.98 & 0.018 & 0.013 \\
\hline 5 & $\sqrt{ }$ depth & 0.0074 & 0.7766 & 550.52 & 8.57 & 0.014 & 0.010 \\
\hline 3 & $\sqrt{ }$ Sed P & 0.0034 & 0.7721 & 551.11 & 9.16 & 0.010 & 0.007 \\
\hline 6 & $\sqrt{ }$ Sed P, $\sqrt{ }$ Sed N & 0.0153 & 0.7769 & 556.00 & 14.05 & 0.001 & 0.001 \\
\hline 8 & $\sqrt{ }$ Sed P, $\sqrt{ }$ Sed N, TNw, TPw & 0.1086 & 0.7810 & 560.59 & 18.64 & 0.000 & 0.000 \\
\hline 9 & Sed P, Sed N, TNw, TPw, depth & 0.1170 & 0.7855 & 564.79 & 22.84 & 0.000 & 0.000 \\
\hline \multicolumn{8}{|l|}{ Post hoc } \\
\hline & Null model & 0 & 0.7654 & 541.95 & 0 & 1 & 0.960 \\
\hline 1 & Sed $\mathrm{NO}_{3}, \mathrm{TNw}$ & 0.1084 & 0.7724 & 550.11 & 8.16 & 0.017 & 0.016 \\
\hline 5 & Sed $\mathrm{NO}_{3}$ & 0.0069 & 0.7705 & 550.68 & 8.73 & 0.013 & 0.012 \\
\hline 7 & longitude, latitude & 0.0548 & 0.7782 & 552.92 & 10.97 & 0.004 & 0.004 \\
\hline 2 & Sed $\mathrm{NO}_{3}, \mathrm{TNw}, \mathrm{TPw}$ & 0.1135 & 0.7754 & 554.07 & 12.12 & 0.002 & 0.002 \\
\hline 4 & $\mathrm{pH}, \mathrm{Temp}_{\mathrm{w}}$ & 0.1308 & 0.7804 & 555.70 & 13.75 & 0.001 & 0.001 \\
\hline 8 & Sed $\mathrm{NO}_{3}, \mathrm{Temp}_{\mathrm{w}}$ & 0.0077 & 0.7757 & 555.94 & 13.99 & 0.001 & 0.001 \\
\hline 3 & $\sqrt{ }$ Sed P, $\sqrt{ }$ Sed N & 0.0153 & 0.7769 & 556.00 & 14.05 & 0.001 & 0.001 \\
\hline 6 & Sed $\mathrm{NO}_{3}, \mathrm{pH}$ & 0.0064 & 0.7757 & 556.02 & 14.07 & 0.001 & 0.001 \\
\hline 9 & Sed $\mathrm{NO}_{3}, \sqrt{ }$ Sed P & 0.0103 & 0.7730 & 556.60 & 14.65 & 0.001 & 0.001 \\
\hline 17 & Sed $\mathrm{NO}_{3}, \mathrm{TNw}, \mathrm{TPw}$, latitude & 0.1338 & 0.7763 & 557.89 & 15.94 & 0.000 & 0.000 \\
\hline 16 & Sed $\mathrm{NO}_{3}, \mathrm{TNw}, \mathrm{TPw}$, latitude, Temp $\mathrm{w}_{\mathrm{w}}$ & 0.1828 & 0.7758 & 559.03 & 17.08 & 0.000 & 0.000 \\
\hline 10 & Sed $\mathrm{NO}_{3}, \mathrm{TNw}$, latitude, Temp $\mathrm{w}, \mathrm{pH}$ & 0.1872 & 0.7755 & 560.02 & 18.07 & 0.000 & 0.000 \\
\hline 11 & Sed $\mathrm{NO}_{3}, \mathrm{pH}, \mathrm{Temp}_{\mathrm{w}}$ & 0.0073 & 0.7814 & 561.17 & 19.22 & 0.000 & 0.000 \\
\hline 14 & Sed $\mathrm{NO}_{3}, \mathrm{TNw}, \mathrm{TPw}$, latitude, longitude & 0.1308 & 0.7804 & 563.12 & 21.17 & 0.000 & 0.000 \\
\hline 12 & Sed $\mathrm{NO}_{3}, \mathrm{TNw}, \mathrm{TPw}$, latitude, $\sqrt{ }$ Sed $\mathrm{P}$ & 0.1338 & 0.7763 & 564.12 & 22.17 & 0.000 & 0.000 \\
\hline 15 & Sed $\mathrm{NO}_{3}, \mathrm{TNw}, \mathrm{TPw}$, latitude, Temp ${ }_{\mathrm{w}}, \mathrm{pH}$ & 0.1841 & 0.7788 & 564.68 & 22.73 & 0.000 & 0.000 \\
\hline \multirow[t]{2}{*}{13} & Sed $\mathrm{NO}_{3}, \mathrm{TNw}$, latitude, Temp $\mathrm{w}, \mathrm{pH}, \sqrt{ }$ depth & 0.1848 & 0.7782 & 566.08 & 24.13 & 0.000 & 0.000 \\
\hline & Global model & 0.1762 & 0.7892 & 581.70 & 39.75 & 0.000 & 0.000 \\
\hline
\end{tabular}

Variables are transformed as indicated to meet assumptions of LME. Also presented are the marginal $\mathrm{R}^{2}\left(R_{M}^{2}\right)$ and conditional $\mathrm{R}^{2}$ $\left(R_{C}^{2}\right)$ values, change in $\operatorname{AIC}_{\mathrm{c}}\left(\Delta_{\mathrm{i}}\right)$, relative model likelihood, and model weight $\left(\omega_{\mathrm{i}}\right)$

Sed $P$ bioavailable phosphorus in sediment in the form of Olsen-P, Sed $N$ nitrate and ammonia in sediment, Sed $\mathrm{NO}_{3}$ nitrate in sediment, $T N w$ total nitrogen in water, $T P w$ total phosphorus in water, $T e m p_{w}$ water temperature

of 0.2 , though the weight of the null model was $3.5 \times$ times greater (0.71). The $\mathrm{R}^{2}$ values show that the fixed factor of the model (TNw) explained about $10 \%$ of variation in leaf length, and the fixed and random terms combined explained $77 \%$ of variation.
Similarly, post hoc comparisons showed that the null model was the best model for both leaf length (Table 3) and leaf shape (Table 4), suggesting that variables not considered in this study or random variation are influencing leaf traits. All other models were considered not plausible, based on $\Delta \mathrm{i}$ values greater than 7 . 
Table 4 Comparison of a priori and post hoc models for predicting leaf shape of emergent Sagittaria cuneata leaves in 15 streams of the Red River Valley, Manitoba, Canada in

\begin{tabular}{|c|c|c|c|c|c|c|c|}
\hline Model \# & Model variables & $R_{M}^{2}$ & $R_{C}^{2}$ & $\mathrm{AIC}_{\mathrm{c}}$ & $\Delta_{\mathrm{i}}$ & Likelihood & $\omega_{\mathrm{i}}$ \\
\hline \multicolumn{8}{|l|}{ A priori } \\
\hline & Null model & 0.00 & 0.60 & -1260.23 & 0.00 & 1.000 & 0.986 \\
\hline 2 & $\mathrm{TNw}$ & 0.09 & 0.61 & -1250.41 & 9.82 & 0.007 & 0.007 \\
\hline 1 & $\mathrm{TPw}$ & 0.07 & 0.61 & -1249.09 & 11.14 & 0.004 & 0.004 \\
\hline 5 & $\sqrt{\text { depth }}$ & 0.03 & 0.63 & -1247.96 & 12.27 & 0.002 & 0.002 \\
\hline 4 & $\sqrt{ }$ Sed N & 0.00 & 0.61 & -1244.51 & 15.72 & 0.000 & 0.000 \\
\hline 3 & $\sqrt{ }$ Sed P & 0.00 & 0.61 & -1244.31 & 15.92 & 0.000 & 0.000 \\
\hline 7 & TNw, TPw & 0.09 & 0.62 & -1243.02 & 17.21 & 0.000 & 0.000 \\
\hline 6 & $\sqrt{ }$ Sed P, $\sqrt{ }$ Sed N & 0.00 & 0.61 & -1234.93 & 25.30 & 0.000 & 0.000 \\
\hline 8 & $\sqrt{ }$ Sed P, $\sqrt{ }$ Sed N, TNw, TPw & 0.09 & 0.62 & -1223.87 & 36.36 & 0.000 & 0.000 \\
\hline 9 & Sed P, Sed N, TNw, TPw, depth & 0.11 & 0.64 & -1218.12 & 42.11 & 0.000 & 0.000 \\
\hline \multicolumn{8}{|l|}{ Post hoc } \\
\hline & Null model & 0.00 & 0.60 & -1260.23 & 0.00 & 1.000 & 1.000 \\
\hline 1 & Sed $\mathrm{NO}_{3}, \mathrm{TNw}$ & 0.09 & 0.61 & -1240.78 & 19.45 & 0.000 & 0.000 \\
\hline 2 & Sed $\mathrm{NO}_{3}, \mathrm{TNw}, \mathrm{TPw}$ & 0.09 & 0.62 & -1233.40 & 26.83 & 0.000 & 0.000 \\
\hline 5 & Sed $\mathrm{NO}_{3}$ & 0.00 & 0.61 & -1244.36 & 15.87 & 0.000 & 0.000 \\
\hline 10 & Sed $\mathrm{NO}_{3}, \mathrm{TNw}$, latitude, Temp & 0.09 & 0.64 & -1216.23 & 44.00 & 0.000 & 0.000 \\
\hline 7 & longitude, latitude & 0.01 & 0.63 & -1237.82 & 22.41 & 0.000 & 0.000 \\
\hline 16 & Sed $\mathrm{NO}_{3}, \mathrm{TNw}, \mathrm{TPw}$, latitude, Temp & 0.09 & 0.64 & -1217.59 & 42.64 & 0.000 & 0.000 \\
\hline 17 & Sed $\mathrm{NO}_{3}, \mathrm{TNw}$, TPw, latitude & 0.09 & 0.63 & -1225.09 & 35.14 & 0.000 & 0.000 \\
\hline 4 & $\mathrm{pH}, \mathrm{Temp}_{\mathrm{w}}$ & 0.01 & 0.63 & -1237.82 & 22.41 & 0.000 & 0.000 \\
\hline 3 & $\sqrt{ }$ Sed $P, \sqrt{ }$ Sed $N$ & 0.00 & 0.61 & -1234.93 & 25.30 & 0.000 & 0.000 \\
\hline 6 & Sed $\mathrm{NO}_{3}, \mathrm{pH}$ & 0.01 & 0.62 & -1236.30 & 23.93 & 0.000 & 0.000 \\
\hline 8 & Sed $\mathrm{NO}_{3}, \mathrm{Temp}_{\mathrm{w}}$ & 0.01 & 0.62 & -1236.35 & 23.88 & 0.000 & 0.000 \\
\hline 9 & Sed $\mathrm{NO}_{3}, \sqrt{ }$ Sed $\mathrm{P}$ & 0.00 & 0.61 & -1234.76 & 25.47 & 0.000 & 0.000 \\
\hline 15 & Sed $\mathrm{NO}_{3}, \mathrm{TNw}, \mathrm{TPw}$, latitude, Temp $\mathrm{w}, \mathrm{pH}$ & 0.09 & 0.65 & -1209.43 & 50.80 & 0.000 & 0.000 \\
\hline 13 & Sed $\mathrm{NO}_{3}, \mathrm{TNw}$, latitude, Temp $\mathrm{w}, \mathrm{pH}, \sqrt{ }$ depth & 0.11 & 0.66 & -1210.35 & 49.88 & 0.000 & 0.000 \\
\hline 14 & Sed $\mathrm{NO}_{3}, \mathrm{TNw}, \mathrm{TPw}$, latitude, longitude & 0.14 & 0.63 & -1220.37 & 39.86 & 0.000 & 0.000 \\
\hline 12 & Sed $\mathrm{NO}_{3}, \mathrm{TNw}, \mathrm{TPw}$, latitude, $\sqrt{ }$ Sed $\mathrm{P}$ & 0.09 & 0.63 & -1215.49 & 44.74 & 0.000 & 0.000 \\
\hline \multirow[t]{2}{*}{11} & Sed $\mathrm{NO}_{3}, \mathrm{pH}, \mathrm{Temp}_{\mathrm{w}}$ & 0.01 & 0.63 & -1228.29 & 31.94 & 0.000 & 0.000 \\
\hline & Global model & 0.19 & 0.64 & -1193.00 & 67.23 & 0.000 & 0.000 \\
\hline
\end{tabular}

Variables are transformed as indicated to meet assumptions of LME. Also presented are the marginal $\mathrm{R}^{2}\left(R_{M}^{2}\right)$ and conditional $\mathrm{R}^{2}$ $\left(R_{C}^{2}\right)$ values, change in $\operatorname{AIC}_{\mathrm{c}}\left(\Delta_{\mathrm{i}}\right)$, relative model likelihood, and model weight $\left(\omega_{\mathrm{i}}\right)$

Sed $P$ bioavailable phosphorus in sediment in the form of Olsen-P, Sed $N$ nitrate and ammonia in sediment, Sed $\mathrm{NO}_{3}$ nitrate in sediment, $T N w$ total nitrogen in water, $T P w$ total phosphorus in water, $T e m p_{w}$ water temperature

\section{Discussion}

When the emergent plant Sagittaria cuneata was grown under controlled conditions, extreme differences were observed between plants growing in nutrient-enriched sediment and those propagated in
August 2014, using linear mixed effects (LME) models and corrected Akaike Information Criterion (AICc) 
plants produced more tubers and leaves than control plants. Many submerged aquatic macrophytes preferentially utilize sediment nutrients over water nutrients (Nichols and Keeney 1976a, b; Best and Mantai 1978; Carignan and Kalff 1980; Barko and Smart 1980, 1981, 1986; Chambers and Kalff 1985; Smith and Adams 1986; Madsen et al. 2001), although highly enriched water can sometimes offset the effects of low nutrient sediments (e.g., Rattray et al. 1991). Our observations that sediment trial plants were more productive and had higher AG:BG ratio than either water or control trial plants indicate that the emergent $S$. cuneata was accessing and utilizing sediment nutrient sources. Plants in the control trial grew poorly and often remained in submerged form, indicating that they did not have access to sufficient nutrients to reach maturity and thus produce emergent leaves and numerous reproductive propagules. The finding that AG:BG biomass ratios were greater for the sedimentenriched plants compared to both the water-enriched and control trials is consistent with our hypothesis of nutrient insufficiency in the latter two trials, as both terrestrial and aquatic plants allocate resources to belowground production instead of aboveground structures (Neill 1990; Hossain et al. 2004; Ket et al. 2011) when nutrient availability is limited (Darby and Turner 2008).

In addition to differences in productivity in response to nutrient enrichment, emergent leaf morphology varied among the three experimental trials. Leaf size of other species of Sagittaria, as well as various terrestrial plant species (Medina 1970; Atkinson 1973; Gulmon and Chu 1981; Jurik et al. 1982), has been shown to respond to nutrient availability. For example, leaf size of $S$. latifolia and blade width of $S$. lancifolia leaves were found to be larger in higher nutrient environments (Dorken and Barrett 2004, Richards and Ivey 2004), consistent with our experimental observations. Wooten (1986) reported a decrease in leaf size with increasing water depth for several Sagittaria spp; however, water depth was, on average, consistent among our nutrient treatments and thus unlikely to be influencing leaf size. Rather, nutrients added to sediments were responsible for the increased leaf size (and greater productivity) of sediment trial plants. In addition, leaf shape of Sagittaria has been shown to vary with nutrient availability: leaf shape of monoecious and dioecious $S$. latifolia plants changed based on resource availability and leaf age, producing thinner leaves when grown in high compared to low fertilizer treatments and with more pronounced differences later in the growth cycle (Dorken and Barrett 2004). Our experimental study also found differences in leaf shape in response to nutrient-enrichment and with plant maturation, with $S$. cuneata plants in the sediment trial producing leaves with lobes that were close together initially that later changed to leaves with lobes that were further apart. Availability of nutrients for plant uptake has farreaching implications: leaves of varying shape (i.e., Nicotra et al. 2011) and larger size increase photosynthetic area (Parkhurst and Loucks 1972; Jurik et al. 1982; Niinemets and Kull 1994) and, hence, energy accrual which, in turn, is manifest in greater clonal (i.e., tuber production) or sexual reproduction (i.e., flower and seed production) (Bazzaz et al. 1987; Reekie and Bazzaz 1987). In the case of $S$. cuneata, leaf size began to decrease near the end of the growing season (weeks 9 and 10), and leaf shape reverted to earlier shapes when plants were allocating nutrients to production of over-wintering propagules. In fact, upon harvesting sediment trial plants were found to have 6.4 and 15.2X more tubers than the water and control trials, respectively, thus ensuring a greater likelihood of survival and regeneration during the following year.

Leaf morphology from the field study was markedly different from that of the experimental study. Rather than the strong response to sediment nutrients shown by experimental plants, field collected plants exhibited extreme variability in leaf morphology that was not explained by sediment nutrients or multiple other abiotic variables. Instead, random chance (or variables such as water velocity and turbidity that were not included in our field study but held constant in the experimental study) may have strongly influenced leaf morphology of $S$. cuneata under natural conditions. Results of nested ANOVAs of leaf length and shape suggest that leaf morphology is governed by complicated processes operating at a variety of scales: leaf, plant, quadrat and site scale, such that leaf length exhibited similar variance at all four scales whereas leaf shape was most variable at extreme scales (leaf and site). Site scale variation is likely related to the genetics of the population since $S$. cuneata generally reproduces clonally, as do most macrophytes (Jones et al. 2012); thus, plants within a site are more genetically similar than plants from different sites. Variation in leaf traits undoubtedly also occurs 
because of environmental heterogeneity (quadrat scale); differences in plant age, resource availability, and the competitive interaction for resources amongst plants of different age (plant scale); and within plant variation of leaf age (leaf scale). To our knowledge, there are no studies that have quantified patterns of variation in leaf characteristics within and among Sagittaria cuneata populations. However, in the case of terrestrial plants, Bruschi et al. (2003) observed that for the sessile oak Quercus petraea, morphological traits such as leaf length and leaf width varied within a single tree, among trees in a single population, and among populations, with the variance in morphological traits being almost equal (14-20\%) among these three scales. Collectively, these findings emphasize the need to standardize sampling design when collecting leaves for autecological and taxonomic studies. This is particularly true for aquatic macrophytes as many species (such as $S$. cuneata) exhibit highly variable leaf plasticity.

Collectively, the experimental and field studies show that leaf development of Sagittaria cuneata is a complicated process: under controlled settings, sediment nutrients drive plant growth whereas under field conditions, leaf morphology is highly variable at all hierarchical scales, with no over-arching environmental drivers. Though results of both studies provide new information on the life history of S. cuneata and the relationship between leaf morphology and its surrounding environment, the variability of leaf morphology in the field proves difficult for use as a bioindicator. A good bioindicator should show greatest variability at the site scale, with the trait or metric showing a dose response to the environmental stressor. However, the field study demonstrated relatively equal variability of leaf traits among the leaf, plant, quadrat and site scales, suggesting large natural variability within the species, populations, and individuals. Sagittaria cuneata is currently not a reliable indicator of stream nutrients, though further in situ study could tease apart the influences of stream variables and characteristics on leaf morphology of S. cuneata. Our results do, however, emphasize the need to quantify within and among plant variation in leaf morphology, especially for aquatic macrophytes. The latter represent a diverse group of aquatic photosynthetic organisms with leaf (or frond) size ranging from $<0.5 \mathrm{~mm}$ to $2.5 \mathrm{~m}$ (Chambers et al. 2008) that are often identified based on growth form and foliage characteristics.
Sampling methods that do not account for high variation in leaf morphology may exacerbate the already notorious difficulty in classifying many taxa of aquatic plants.

Acknowledgements This study benefitted from suggestions from anonymous reviewers, J. Lento, M. Barbeau, M. Methven and C. Tyrrell, assistance from J. Musetta-Lambert, C. Thompson, K. Doucet, R. Casey, K. Roach and M. Deschenes, and laboratory work from National Laboratory for Environmental Testing in Burlington, ON, M. Ma et al. at University of Alberta, C. Drury et al. at Agriculture and Agri Food Canada in Harrow, ON, and P. Dubé et al. at Institut de Recherche et de Développement en Agroenvironnement in Québec, QC. We also wish to acknowledge funding from Environment Canada's Lake Winnipeg Basin Initiative, Canadian Rivers Institute, and Canadian Water Network. KMS was supported by a Collaborative Research and Training Experience (CREATE) grant, and Discovery grants to JMC from the Natural Sciences and Engineering Research Council.

Author contributions KMS designed, executed, and collected and analysed data pertaining to this study. KMS also prepared this manuscript. PAC and JMC assisted in experimental design and execution, advised in statistical methods and interpretation, and provided editorial comments on this manuscript.

Open Access This article is distributed under the terms of the Creative Commons Attribution 4.0 International License (http:// creativecommons.org/licenses/by/4.0/), which permits unrestricted use, distribution, and reproduction in any medium, provided you give appropriate credit to the original author(s) and the source, provide a link to the Creative Commons license, and indicate if changes were made.

\section{References}

Adams D, Otarola-Castillo E (2013) Geomorph: an R package for the collection and analysis of geometric shape data. Methods Ecol Evol 4:393-399

Adams D, Rohlf F, Slice D (2004) Geometric morphometrics: ten years of progress following the 'revolution'. Ital J Zool 71:5-16

Adams D, Rohlf F, Slice D (2012) A field comes of age: geometric morphometrics in the 21 st century. Hystrix 24(1):7-14

American Public Health Association (APHA) (2005a) Standard Methods for the Examination of Water and Wastewater, 21st ed method 4500-N C persulfate method. American Public Health Association, Washington, DC, USA

American Public Health Association (2005b) Standard methods for the examination of water and wastewater, 21st edn method 4500-P D stannous chloride method. American Public Health Association, Washington, DC, USA

American Public Health Association (2012) Standard methods for the examination of water and wastewater, $22 \mathrm{edn}$. TP/ 
TDP-Method 4500-P-G. American Public Health Association, Washington, DC

Anderson D (2008) Model based inference in the life sciences: a primer on evidence. Springer, New York

Arber A (1920) Water plants-a study of aquatic angiosperms. Cambridge University Press, Cambridge

Atkinson D (1973) Some general effects of phosphorus deficiency on growth and development. New Phytol 71:101-111

Barko J, Smart R (1980) Mobilization of sediment phosphorus by submersed freshwater macrophytes. Freshw Biol 10:229-238

Barko J, Smart R (1981) Sediment based nutrition of submersed macrophytes. Aquat Bot 10:339-352

Barko J, Smart R (1986) Sediment-related mechanisms of growth limitation in submersed macrophytes. Ecology 67:1328-1340

Bates D, Maechler M, Bolker B, Walker S (2014) lme4: linear mixed-effects models using Eigen and S4. R package version 1.1-7. http://CRAN.R-project.org/package=lme4

Bazzaz F, Chiariello N, Coley P, Pitelka L (1987) Allocating resources to reproduction and defense. Bioscience 37(1):58-67

Best M, Mantai K (1978) Growth of Myriophyllum: sediment or lake water as the source of nitrogen and phosphorus. Ecology 59:1075-1080

Bruschi P, Grossoni P, Bussotti F (2003) Within-and among-tree variation in leaf morphology of Quercus petraea (Matt.) Liebl. natural populations. Trees 17:164-172

Carbiener R, Trémolières M, Mercier J, Ortscheidt A (1990) Aquatic macrophytes communities as bioindicators of eutrophication in calcareous oligosaprobe stream waters (Upper Rhine plaine, Alsace). Vegetatio 86:71-88

Carignan R, Kalff J (1980) Phosphorus sources for aquatic weeds: water or sediments? Science 207:987-988

Ceschin S, Zuccarello V, Caneva G (2010) Role of macrophyte communities as bioindicators of water quality: application on the Tiber River basin (Italy). Plant Biosys 144(3):528-536

Chambers PA (1987) Light and nutrients in the control of aquatic plant community structure. II. In situ observations. J Ecol 75:621-628

Chambers P, Kalff J (1985) The influence of sediment composition and irradiance on growth and morphology of Myriophyllum spicatum L. Aquat Bot 22:253-263

Chambers P, Lacoul P, Murphy K, Thomaz S (2008) Global diversity of aquatic macrophytes in freshwater. Hydrobiologia 595(1):9-26

Clements W, Carlisle D (2000) Heavy metals structure benthic communities in Colorado mountain streams. Ecol Appl 10:626-638

Cornelissen J, Lavorel S, Garnier E, Díaz S, Buchmann N, Gurvich D, Reich P, ter Steege H, Morgan H, van der Heijden M, Pausas J, Poorter H (2003) A handbook of protocols for standardised and easy measurement of plant functional traits worldwide. Aust J Bot 51:335-380

Crow G, Hellquist C (2000) Aquatic and wetland plants of northeastern North America, vol 2. Angiosperms, monocotyledons. University of Wisconsin Press, Madison
Darby F, Turner R (2008) Below- and aboveground biomass of Spartina alterniflora: response to nutrient addition in a Louisiana salt marsh. Estuar Coast 31(2):326-334

Demars B, Harper D (1998) The aquatic macrophytes of an English lowland river system: assessing response to nutrient enrichment. Hyrdobiologia 384:75-88

Dodds W, Gido K, Whiles M, Fritz K, Matthews W (2004) Life on the edge: the ecology of Great Plains prairie streams. Bioscience 54:205-216

Donald D, Cessna A, Sverko E, Glozier N (2007) Pesticides in surface drinking-water supplies of the northern Great Plains. Environ Health Perspect 115:1183-1191

Dorken M, Barrett S (2004) Phenotypic plasticity of vegetative and reproductive traits in monoecious and dioecious populations of Sagittaria latifolia (Alismataceae): a clonal aquatic plant. J Ecol 92:32-44

Downing J, Anderson M (1985) Estimating standing biomass of aquatic macrophytes. Can J Fish Aquat Sci 42:1860-1869

Environment Canada, Manitoba Water Stewardship (2011) State of Lake Winnipeg: 1999-2007. https://www.gov.mb. ca/waterstewardship/water_quality/state_lk_winnipeg_ report/pdf/state_of_lake_winnipeg_rpt_technical_low_ resolutionpdf. Accessed 11 June 2013

Fernald M (1950) Gray's manual of botany. American Book Company, New York

Gower J (1975) Generalized Procrustes analysis. Psychometrika 40:33-51

Gulmon S, Chu C (1981) The effects of light and nitrogen on photosynthesis, leaf characteristics, and dry matter allocation in the chaparral shrub, Diplacus aurantiacus. Oecologia 49:207-212

Hall R, Leavitt P, Quinlan R, Dixit A, Smol J (1999) Effects of agriculture, urbanization, and climate on water quality in the northern Great Plains. Limnol Oceanogr 44:739-756

Haury J, Peltre MC, Trémolières M, Barbe J, Thiébaut G, Bernez I, Daniel H, Chatenet P, Haan-Archipof G, Muller S, Dutartre A, Laplace-Treyture C, Cazaubon A, LambertServien E (2006) A new method to assess water trophy and organic pollution-The Macrophyte Biological Index for Rivers (IBMR): its application to different types of river and pollution. Hydrobiologia 570:153-158

Hodkinson I, Jackson J (2005) Terrestrial and aquatic invertebrates as bioindicators for environmental monitoring, with particular reference to mountain ecosystems. Environ Manag 35(5):649-666

Holt E, Miller S (2011) Bioindicators: using organisms to measure environmental impacts. Nat Educ Knowl 3(10):8

Hossain M, Ishimine Y, Hikaru A, Kuramochi H (2004) Effect of nitrogen fertilizer application on growth, biomass production and $\mathrm{N}$-uptake of torpedograss (Panicum repens $\mathrm{L}$ ). Weed Biol Manag 4:86-94

Huebert D, Gorham P (1983) Biphasic mineral nutrition of the submersed aquatic macrophyte Potamogeton pectinatus L. Aquat Bot 16(3):269-284

Hunter-Cario L (2007) Propagation protocol for broadleaf arrowhead Sagittaria latifolia Willd (Alismataceae). Nativ Plants J 8(2):80-83

Hurvich C, Tsai C-L (1991) Bias of the corrected AIC criterion for underfitted regression and time series models. Biometrika 78:499-509 
Jones J, Collins A, Naden P, Sear D (2012) The relationship between fine sediment and macrophytes in rivers. River Res Appl 28:1006-1018

Jurik T, Chabot J, Chabot B (1982) Effects of light and nutrients on leaf size, $\mathrm{CO}_{2}$, exchange, and anatomy in wild strawberry (Fragaria virginiana). Plant Physiol 70(4):1044-1048

Keeney D, Nelson D (1982) Nitrogen-inorganic forms method 33-32. In: Page A (ed) Methods of soil analysis Part 2 chemical and microbiological properties, 2nd edn. Madison, USA, pp 643-698

Ket W, Schubauer-Berigan J, Craft C (2011) Effects of five years of nitrogen and phosphorus additions on a Zizaniopsis miliacea tidal freshwater marsh. Aquat Bot 95(1):17-23

Madsen J, Chambers P, James W, Koch E, Westlake D (2001) The interaction between water movement, sediment dynamics and submersed macrophytes. Hydrobiologia 444:71-84

Mazerolle M (2015) AICcmodavg: model selection and multimodel inference based on(Q)AIC(c). R package version 2.0-3. http://CRAN.Rproject.org/package=AICcmodavg

McIninch S, Garbisch E (1991) Oxygen requirement of dormant wetland plants. Wildflower 4:8-13

Medina E (1970) Relationship between nitrogen level, photosynthetic capacity, and carboxydismutase activity in Atriplex patula leaves. Year Book 69:655-662

Mitteroecker P, Gunz P (2009) Advances in geometric morphometrics. Evol Biol 36:235-247

Neill C (1990) Effects of nutrients and water levels on emergent macrophyte biomass in a prairie marsh. Can $\mathrm{J}$ Bot 68:1007-1014

Nichols D, Keeney D (1976a) Nitrogen nutrition of Myriophyllum spicatum: variation of plant tissue nitrogen concentration with season and site in Lake Wingra. Freshw Biol 6:137-144

Nichols D, Keeney D (1976b) Nitrogen nutrition of Myriophyllum spicatum: uptake and translocation of $\mathrm{N}$ by shoots and roots. Freshw Biol 6:145-154

Nicotra A, Leigh A, Boyce C, Jones C, Niklas K, Royer D, Tsukaya $H$ (2011) The evolution and functional significance of leaf shape in the angiosperms. Funct Plant Biol 38:535-552

Niinemets U, Kull K (1994) Leaf weight per area and leaf size of 85 Estonian woody species in relation to shade tolerance and light availability. Forest Ecol Manag 70:1-10

Olsen S, Cole C, Watanabe F, Dean L (1954) Estimation of available phosphorus in soils by extraction with sodium bicarbonate. USDA circular 939. US Government Printing Office, Washington, DC, USA

Parkhurst D, Loucks O (1972) Optimal leaf size in relation to environment. J Ecol 60(2):505-537

Pelton D, Levine S, Braner M (1998) Measurements of phosphorus uptake by macrophytes and epiphytes from the LaPlatte River (VT) using 32P in stream microcosms. Freshw Biol 39(2):285-299

Rasband WS (1997-2014) ImageJ, U S National Institutes of Health, Bethesda, Maryland, USA. http://imagej.nih.gov/ ij/. Accessed 7 May 2013

Rattray M, Howard-Williams C, Brown J (1991) Sediment and water as sources of nitrogen and phosphorus for submerged rooted aquatic macrophytes. Aquat Bot 40(3):225-237
Red River Basin Board (2000) Inventory team report: hydrology. http://www.redriverbasincommission.org/hydrology_ report.PDF

Reekie E, Bazzaz F (1987) Reproductive effort in plants. 3. Effect of reproduction on vegetative activity. Amer Nat 129(6):907-919

Richards J, Ivey C (2004) Morphological plasticity of Sagittaria lancifolia in response to phosphorus. Aquat Bot 80:53-67

Robach F, Thiébaut G, Trémolières M, Muller S (1996) A reference system for continental running waters: plant communities as bioindicators of increasing eutrophication in alkaline and acid waters in north-east France. Hydrobiologia 341:67-76

Rohlf F, Slice D (1990) Extensions of the Procrustes method for the optimal superimposition of landmarks. Syst Zool 39:40-59

Samson F, Knopf F (1994) Prairie conservation in North America. Bioscience 44:418-421

Sculthorpe C (1967) The biology of aquatic vascular plants. Edward Arnold Publishers Ltd, London

Sharma R, Rawat J (2009) Monitoring of aquatic macroinvertebrates as bioindicator for assessing the health of wetlands: a case study in the Central Himalayas, India. Ecol Indic 9(1):118-128

Smith C, Adams M (1986) Phosphorus transfer from sediment by Myriophyllum spicatum. Limnol Oceanogr 31:1312-1321

Sugiura N (1978) Further analysis of the data by Akaike's information criterion and the finite corrections. Commun Stat Theory Methods A7:13-26

Thiébaut G, Muller S (1999) A macrophyte communities sequence as an indicator of eutrophication and acidification levels in weakly mineralised streams in north-eastern France. Hydrobiologia 410:17-24

Tremp H, Kohler A (1995) The usefulness of macrophyte monitoring-system, exemplified on eutrophication and acidification of running waters. Acta Bot Gallica 142(6):541-550

Underwood AJ (1997) Experiments in ecology: Their logical design and interpretation using analysis of variance. Cambridge University Press, Cambridge, UK

United States Environmental Protection Agency (USEPA) (1993) Determination of total nitrogen by automated colorimetry, Method 353.2. Environmental Monitoring Systems Laboratory Office of Research and Development, Cincinnati, $\mathrm{OH}$

Willis R, Gentry C (1987) Automated method for determining nitrate and nitrite in water and soil extracts. Commun Soil Sci Plant Anal 18:625-636

Wooten J (1986) Variations in leaf characteristics of six species of Sagittaria (Alismataceae) caused by various water levels. Aquat Bot 23:321-327

Yates A, Culp J, Chambers P (2012) Estimating nutrient production from human activities in subcatchments of the Red River, Manitoba. J Great Lakes Res 38:106-114

Zelditch M, Swiderski D, Sheets H, Fink W (2004) Geometric morphometrics for biologists: a primer. Elsevier/Academic Press, Amsterdam 